Original Article

\title{
IN SILICO AND IN VITRO ASSAY OF HGV ANALOGUE AS ANTIBACTERIAL
}

\author{
BAMBANG WIJIANTOab, RITMALENI ${ }^{a}{ }^{*}$, HARI PURNOMOa , ARIEF NURROCHMAD ${ }^{a}$ \\ aFaculty of Pharmacy, Universitas Gadjah Mada Yogyakarta 55281 and University of Tanjungpura, Pontianak, Indonesia \\ Email: ritmaleni@ugm.ac.id
}

Received: 31 Oct 2018 Revised and Accepted: 26 Jan 2019

\section{ABSTRACT}

Objective: The objective of this research was to design a new analogue compound, hexagamavunon (HGV).

Methods: New design of analogue compound, HGV, was performed by QSAR study using BuildQSAR program. In this QSAR study, parameterized model (PM3) method using the Polak-Ribière algorithm was applied to calculate the optimal geometric structures of the used compounds. The new analogue compound, HGV had been synthesized using aldol condensation reaction. The assay of antibacterial activities was performed using the dilution method. Molecular operating environment (MOE) program was used for protocol docking

Results: The results of QSAR study reveal the good relationship of antibacterial activities. The in vitro antibacterial activities of 2,6-bis((E)-3,5dibromo-4-hydroxybenzylidene) cyclohexan-1-one (A113) indicates the good potential to against S. aureus, B. subtilis and E. coli with IC 5027.3 $\mu \mathrm{g} / \mathrm{ml}, 30.9 \mu \mathrm{g} / \mathrm{ml}, 32 \mu \mathrm{g} / \mathrm{ml}$ respectively. This is in accordance with the in silico evaluation showing that 2,6-bis((E)-3,5-dibromo-4hydroxybenzylidene) cyclohexan-1-one has lower docking score than both amoxicillin and cefoxitin do as the native ligand of receptor 3MZE.

Conclusion: Based on in silico and in vitro assay, 2,6-bis((E)-3,5-dibromo-4-hydroxybenzylidene) cyclohexan-1-one (A113) has good antibacterial activities against $S$. aureus, B. subtilis, and E. coli.

Keywords: In silico, In vitro, 2,6-bis((E)-3,5-dibromo-4-hydroxybenzylidene)cyclohexan-1-one, Antibacterial

(c) 2019 The Authors. Published by Innovare Academic Sciences Pvt Ltd. This is an open access article under the CC BY license (http://creativecommons.org/licenses/by/4.0/) DOI: http://dx.doi.org/10.22159/ijpps.2019v11i3.30581

\section{INTRODUCTION}

Heksagamavunon (HGV), pentagamavunon (PGV) and gamavuton (GVT) are mono-ketone analogue compounds which have been successfully synthesized and patented. Basically, they are curcumin analogues [1] that have biological activities including antiinflammatory, antioxidant, and antibacterial $[1,2]$. The basic differences of the three compounds refer to the carbonyl ketone group that connects two rings of benzene aromatic (fig. 1). The analogue compounds were synthesized using aldol condensation $[1,3]$.

Bacteria are dangerous microorganisms, some bacteria cause health problems such as typhoid [4], common cold [5], syphilis [6], and more. S. aureus, B. subtilis and E. coli are Gram-positive and Gramnegative bacteria respectively that commonly lead to some diseases such as pneumonia, meningitis, and diarrhea [7]. In addition, they are organism model that is frequently used in antibiotic screening studies [8]. The bacteria are less pathogenic so that they are saved for laboratory experiments.
The drug design for finding new types of medicine can be done using computational chemistry method. This was applied to redesign the molecules of lead compounds for better biological activities and less side effects. Considering time and cost efficiency, quantitative structure-activity relationship (QSAR) is a computational method which can be mainly implemented in finding new drugs. Moreover, it is possible to implement to avoid trial and error with considerable significance or credibility level [9]. QSAR study revealed the quantitative relationship of microscopic (molecular structure) and macroscopic (biological activity) of a molecule. The study on analogue compounds, HGV, PGV, and GVT, was performed for antioxidant activities [10]; it is possible to conduct to predict antibacterial activities.

The objective of this research was to design new analogue compounds involving HGV, PGV, and GVT that are potential to be used as antibacterial. They were synthesized and evaluated for their antibacterial activities against $S$. aureus, B. subtilis and E. coli using the liquid dilution method $[11,12]$.

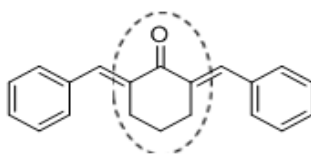

HGV

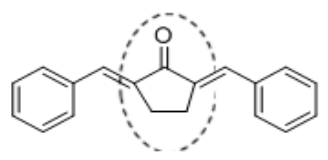

PGV

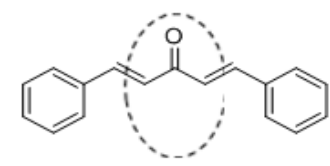

GVT

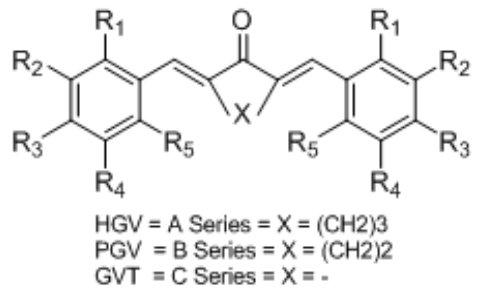

Fig. 1: Basic framework of HGV, PGV, and GVT analogues 
The drug design for finding new types of medicine can be done using computational chemistry method. This was applied to redesign the molecules of lead compounds for better biological activities and less side effects. Considering time and cost efficiency, quantitative structureactivity relationship (QSAR) is a computational method which can be mainly implemented in finding new drugs. Moreover, it is possible to implement to avoid trial and error with considerable significance or credibility level [9]. QSAR study revealed the quantitative relationship of microscopic (molecular structure) and macroscopic (biological activity) of a molecule. The study on analogue compounds, HGV, PGV, and GVT, was performed for antioxidant activities [10]; it is possible to conduct to predict antibacterial activities.

The objective of this research was to design new analogue compounds involving HGV, PGV, and GVT that are potential to be used as antibacterial. They were synthesized and evaluated for their antibacterial activities against $S$. aureus, B. subtilis and E. coli using the liquid dilution method $[11,12]$.

\section{MATERIALS AND METHODS}

\section{Data set QSAR}

In QSAR study, the data set used involve nine compounds of HGV PGV and GVT analogue (unpublished Ritmaleni's collection) with their antibacterial activities against $S$. aureus, ten compounds of HGV, PGV and GVT analogue (unpublished Ritmaleni's collection) with their antibacterial activities against $B$. subtilis, and nine analogue compounds of HGV, PGV and GVT analogue (unpublished Ritmaleni's collection) with their antibacterial activities against $E$. coli (table 1). The in vitro antibacterial activities were interpreted as inhibitory concentration value $\left[\mathrm{IC}_{50}(\mu \mathrm{g} / \mathrm{ml})\right]$ which is logarithmtransformed $\left(\log \mathrm{IC}_{50}\right)$.

Table 1: HGV, PGV, GVT analogues used as data set for QSAR

\begin{tabular}{|c|c|c|c|c|c|c|c|c|}
\hline \multirow[t]{2}{*}{ Comp. } & \multicolumn{5}{|c|}{ Substitute } & \multirow[t]{2}{*}{ S. aureus Log IC50 } & \multirow[t]{2}{*}{ B. subtilis Log IC50 } & \multirow[t]{2}{*}{ E. coli log IC50 } \\
\hline & R1 & R2 & R3 & $\mathbf{R 4}$ & R5 & & & \\
\hline A103 & $\mathrm{H}$ & OC2H5 & $\mathrm{OH}$ & $\mathrm{H}$ & $\mathrm{H}$ & 1.43 & - & 2.22 \\
\hline C113 & $\mathrm{H}$ & $\mathrm{Br}$ & $\mathrm{OH}$ & $\mathrm{Br}$ & $\mathrm{H}$ & - & 2.07 & - \\
\hline B113 & $\mathrm{H}$ & $\mathrm{Br}$ & $\mathrm{OH}$ & $\mathrm{Br}$ & $\mathrm{H}$ & - & 1.92 & 1.71 \\
\hline A114 & $\mathrm{H}$ & $\mathrm{Br}$ & $\mathrm{OH}$ & $\mathrm{H}$ & $\mathrm{H}$ & 1.91 & - & - \\
\hline A101 & $\mathrm{H}$ & ОСН3 & ОСН3 & ОСН3 & $\mathrm{H}$ & 3.02 & 2.71 & - \\
\hline B101 & $\mathrm{H}$ & ОСН3 & ОСН3 & ОСН3 & $\mathrm{H}$ & 2.66 & 2.65 & - \\
\hline C101 & $\mathrm{H}$ & OCH3 & ОСН3 & OCH3 & $\mathrm{H}$ & 2.66 & 2.7 & 2.79 \\
\hline B115 & $\mathrm{H}$ & $\mathrm{Br}$ & $\mathrm{H}$ & $\mathrm{H}$ & OCH3 & 2.83 & 2.74 & - \\
\hline C115 & $\mathrm{H}$ & $\mathrm{Br}$ & $\mathrm{H}$ & $\mathrm{H}$ & OCH3 & - & - & - \\
\hline A145 & $\mathrm{H}$ & $\mathrm{H}$ & $\mathrm{H}$ & $\mathrm{H}$ & OC2H5 & - & - & 2.55 \\
\hline B145 & $\mathrm{H}$ & $\mathrm{H}$ & $\mathrm{H}$ & $\mathrm{H}$ & ОС $2 \mathrm{H} 5$ & 2.78 & 2.66 & 2.6 \\
\hline C145 & $\mathrm{H}$ & $\mathrm{H}$ & $\mathrm{H}$ & $\mathrm{H}$ & ОС2H5 & - & - & - \\
\hline A150 & $\mathrm{Cl}$ & $\mathrm{H}$ & $\mathrm{H}$ & $\mathrm{H}$ & $\mathrm{Cl}$ & 3.05 & - & 2.6 \\
\hline B150 & $\mathrm{Cl}$ & $\mathrm{H}$ & $\mathrm{H}$ & $\mathrm{H}$ & $\mathrm{Cl}$ & - & - & 2.71 \\
\hline C150 & $\mathrm{Cl}$ & $\mathrm{H}$ & $\mathrm{H}$ & $\mathrm{H}$ & $\mathrm{Cl}$ & 2.39 & 2.65 & - \\
\hline A143 & $\mathrm{Cl}$ & $\mathrm{H}$ & $\mathrm{H}$ & $\mathrm{H}$ & $\mathrm{F}$ & - & 2.41 & 2.37 \\
\hline C143 & $\mathrm{Cl}$ & $\mathrm{H}$ & $\mathrm{H}$ & $\mathrm{H}$ & $\mathrm{F}$ & - & 2.26 & 2.23 \\
\hline
\end{tabular}

\section{Instrumentation}

In the QSAR study, a PC with the processor of Intel Core i3-6006U 2.0 $\mathrm{GHz}$, 4GB, Windows 7 Operating System was used. All calculations of quantum mechanics, atomic descriptors and molecular descriptors applied HyperChem 7.5 program. The QSAR model was generated using MLR analysis with BuildQSAR program. Protocol docking was performed with molecular operating environment (MOE) version 2018.0101.

BUCHI Melting Point B-540 with temperature gradient at $5{ }^{\circ} \mathrm{C} / \mathrm{min}$ was used for melting point test. The purity of compounds was measured using GC17A MSQP 5000 Shimadzu. JEOL $500 \mathrm{MHz}$ spectrophotometer was used to measure ${ }^{13} \mathrm{C}$ NMR Spectrum. All of the starting materials were obtained from Sigma Aldrich. The solvent materials used are Synthesis grade and Pro analysis.

\section{Procedure}

\section{QSAR study}

\section{Geometric optimization}

Each leading compound used in the QSAR study (table 1) was transformed into a two-dimensional structure (2D) (fig. 1) with HyperChem program. Atom $\mathrm{H}$ was added to complete the structure to transform it into the three-dimensional structure (3D). Its geometric structure was then optimized with PM3 semi-empirical method using the Polak-Ribière algorithm [10].

\section{Descriptor calculation}

The single point calculation was conducted for the optimized threedimensional structures using HyperChem program. This was to obtain the electronic parameters such as atom C's net charge, total energy (E total), binding energy (BE) and heat of formation (HF); lipophilicity parameters; and steric parameters (molecule size) of each molecule using the HyperChem program [10].

\section{Statistical analysis}

All of the descriptors were analyzed with multilinear regression (MLR) in order to find the antibacterial activities using BuildQSAR program. The best equation models resulted were selected, considering its best statistical parameters, and were used to predict its antibacterial activities. The best statistical parameters involve the highest $R$ (regression), the largest $\mathrm{F}$ ratio, the smallest $\mathrm{s}$ value, the smallest PRESS statistic (the predicted residual sum of squares), and the lowest Q2. The selected equations were validated using the available leave-one-out cross-validation (LOOCV) method of BuildQSAR program.

\section{Docking studies}

\section{Preparation of ligand structures}

A113 (2,6-bis((E)-3,5-dibromo-4-hydroxybenzylidene) cyclohexan1-one) and cefoxitin, the reference molecules of the docking simulations, were built in the two-dimensional model in the form of MOE database. The determination of conformation was then performed on the database using import conformation. Furthermore, its minimal energy was calculated.

\section{Docking simulations}

The 3D Penicillin-Binding Protein 5 (PBP5) was obtained from Protein Data Bank (https://www. rcsb. org/; PDB ID code: 3MZE) [13]. Protein contains a reference molecule that is cefoxitin (3a) as the native ligand. The protein binding sites were managed using modules of Ligand Atoms Selection of MOE, and the cefoxitin binding sites were used in crystal structure as a reference. The sequence order of the binding sites was set using MOE program. Hydrogen was added to complete the protein structure using selected Protonate 3D of MOE program; only ligand and 
protein chain A of the crystal structure was used. The protein was then aligned using Align module of MOE. For the docking simulation process, the placement was managed on triangular matcher, rescoring was managed on London $\mathrm{dG}$ parameter, and the conformation number was managed in 10 poses; conformation was selected as the forcefield of MOE and was used to generate 10 poses. As the results of docking run, the output file is in mdb form with the scoring of some conformations. All of the docking conformations were analyzed, and the best value with the precise pose was selected for the further interactional study.

General procedure for synthesis of A113 (2,6-bis((E)-3,5dibromo-4-hydroxybenzylidene) cyclohexan-1-one)

3.572 mol 3,5,-dibromo-4-dihydroxybenzaldehyde, $1.786 \mathrm{~mol}$ cyclohexanone, $2.0 \mathrm{ml} \mathrm{THF}$ and $0.2 \mathrm{ml}$ of concentrated hydrochloric acid were stirred for two hours at $50{ }^{\circ} \mathrm{C}$, and the stirring was continued for $8 \mathrm{~h}$ at room temperature. After set aside for $3 \mathrm{~d}$, the mixture was treated with cold ethanol-water (1:1), filtered and the residue was dried. TLC, melting point, was used to confirm the purity of the compound.

2,6-bis((E)-3,5-dibromo-4-hydroxybenzylidene) cyclohexan-1one (A113)

Reddish yellow powder, yield $34.84 \%, \mathrm{mp}>300{ }^{\circ} \mathrm{C}$; IR $\gamma\left(\mathrm{cm}^{-1}\right)$ $(\mathrm{KBr})$ : 3485.75-OH stretch non bonded, $2928.87=\mathrm{C}-\mathrm{H}$ stretch aromatic, $1597.95 \mathrm{C}=0$ stretch $\alpha \beta, \alpha^{\prime} \beta^{\prime}$-unsat, 1475.35 $\mathrm{C}=\mathrm{C}$ stretch aromatic, $1165.12 \mathrm{C}-0$ stretch. ${ }^{13} \mathrm{C}-\mathrm{NMR}(500 \mathrm{MHz}$, Asetone-d6) $\delta$ (ppm): 206.258 (C=0 ketone), $188.875(\mathrm{C}-\mathrm{OH}), 151.987$ (C-C aromatic, ketone), $137.550\left(\mathrm{C}=\mathrm{C}\right.$ aliphatic), 133.941 (C-Br). ${ }^{1} \mathrm{HNMR}$ (300 MHz, Asetone-d6) $\delta: 8.98(\mathrm{~s}, 1 \mathrm{H}, \mathrm{OH}), 7.73(\mathrm{~s}, 1 \mathrm{H}, \mathrm{Ar}-\mathrm{H}), 7.531$ (s, $1 \mathrm{H}$, aliphatic), 2.97-2.94 (4H, ketone-H), 2.05-2.04 (2H, ketone-H).

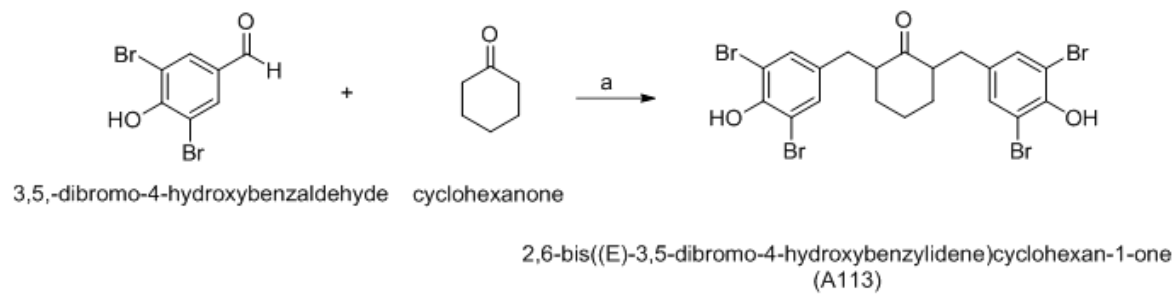

Scheme 1: Reagent and conditions of synthesis: (a) THF and $\mathrm{HCl} ; 8$ h

\section{In vitro antibacterial activity assay}

The antibacterial activities against ATCC 6538P, B. subtilis ATCC 6633 and E. coli ATCC 25922 were tested using liquid dilution method. For in vitro assay, A113 was prepared. BHI media $(50 \mu \mathrm{l})$ was added into microplate 96 well; experimental compound (50 $\mu \mathrm{l})$ was added into $1 \mathrm{~A}$ until $1 \mathrm{E}$ column. The obtained concentrations of the dilution method is $0.5 \mathrm{mg} / \mathrm{ml}, 0.25 \mathrm{mg} / \mathrm{ml}, 0.125 \mathrm{mg} / \mathrm{ml}, 0.063$ $\mathrm{mg} / \mathrm{ml}$, and $0.031 \mathrm{mg} / \mathrm{ml}$ respectively. Selected bacteria $(50 \mu \mathrm{l})$ was added into each well. Solvent control, compound control, and media control were prepared in the same microplate. The incubation was conducted for $24 \mathrm{~h}$ at $37^{\circ} \mathrm{C}$. It was then measured using microplate reader $(595 \mathrm{~nm})$. This method was used to determine the inhibitory concentration of the investigated compounds which showed inhibitory effect on the growth of the tested bacteria. This concentration was considered as inhibitory concentration $\left(\mathrm{IC}_{50}\right)$.

\section{RESULTS AND DISCUSSION}

\section{Selection of the best model}

The new compound design of HGV, PGV, and GVT analogues as antibacterial was conducted based on QSAR study using BuildQSAR. The best equation of QSAR was selected for predicting the antibacterial activities against S. aureus, B. subtilis and E. coli. The selection of descriptors was conducted using systematic search (SS) method. QSAR model consists of one to five variables; it must have correlation criteria, $r>0.8$ and forbid cross-correlation (Rij) $>0.6$. BuildQSAR was validated using leave-one-out cross-validation.

$\mathrm{X} 1$ and X5 were found on the selected variables; it shows the number of selected variables. In addition, the values of R, s, F, Q2, SPress, SDep were identified. The selection was based on the best statistical parameters including the highest $\mathrm{R}$ (regression), the largest $\mathrm{F}$ ratio, the smallest s value, the smallest PRESS statistic (the predicted residual sum of squares), and the lowest Q2. The calculation of MLR of the descriptors of $S$. aureus, B. subtilis and E. coli using BuildQSAR provides 4 QSAR models as shown in table 2, table 3 , and table 4 .

Basically, the best model selected was based on the number of variables and statistical parameters of the model [14]. The results indicate that all models reveal the linear correlation of biological activities and descriptors as indicated by the R-value of each model.

The QSAR equation model (1) of each table was selected for predicting the antibacterial activities $\left(\log \mathrm{IC}_{50}\right)$ against $S$. aureus (table 2), B. subtilis (table 3), and E. coli (table 4); it is the best QSAR model. The equation (1) of each table was selected as it has the most number of variable, the highest R (regression), the largest F (Fisher) coefficient, and the smallest PRESS statistic (the predicted residual sum of squares). Considering the smallest value, the equation was considered as a model closed to the experimental results.

Table 2: Statistical model QSAR and parameter statistical of MLR result against $S$. aureus

\begin{tabular}{|c|c|c|c|c|c|c|c|c|c|c|}
\hline No. & Descriptor & $\mathbf{n}$ & $\mathbf{m}$ & $\mathbf{R}$ & $\mathbf{s}$ & $\mathbf{F}$ & $\mathbf{p}$ & Q2 & SPress & SDep \\
\hline \multirow[t]{2}{*}{1.} & $\begin{array}{l}\text { qC11, qC15, qC16, } \\
\text { qC17, Volum }\end{array}$ & 9 & 5 & 0.998 & 0.052 & 171.136 & 0.0007 & 0.951 & 0.194 & 0.119 \\
\hline & Equation & \multicolumn{9}{|c|}{$\begin{array}{l}\log I C_{50}=-7.5725( \pm 2.9753) \mathrm{qC} 11-6.0978( \pm 0.7519) \mathrm{qC} 15-7.9387( \pm 1.3551) \mathrm{qC} 16-8.3101( \pm 1.7492) \\
\mathrm{qC} 17+0.0061( \pm 0.0010) \text { Volum-5.5336( } \pm 1.3713)\end{array}$} \\
\hline \multirow[t]{2}{*}{2.} & $\mathrm{qC} 4, \mathrm{qC} 5, \mathrm{qC} 14$, Mass & 9 & 4 & 0.986 & 0.125 & 36.048 & 0.0021 & 0.864 & 0.281 & 0.198 \\
\hline & Equation & \multicolumn{9}{|c|}{$\begin{array}{l}\log I C_{50}=+17.9885( \pm 4.6196) \mathrm{qC} 4+5.5044( \pm 2.0227) \mathrm{qC} 5+4.9255( \pm 1.6793) \mathrm{qC} 14+0.0057( \pm 0.0035) \\
\text { Mass }+3.5267( \pm 1.3433)\end{array}$} \\
\hline \multirow[t]{2}{*}{3.} & $\begin{array}{l}\text { qC4, Mass, Surface } \\
\text { Area (SA) }\end{array}$ & 9 & 3 & 0.979 & 0.138 & 38.698 & 0.0007 & 0.867 & 0.248 & 0.196 \\
\hline & Equation & \multicolumn{9}{|c|}{$\log I C_{50}=+18.1619( \pm 4.7645) \mathrm{qC} 4+0.0080( \pm 0.0035)$ Mass $+0.0064( \pm 0.0020)$ SA-1.9560 $( \pm 1.6218)$} \\
\hline \multirow[t]{2}{*}{4.} & $\mathrm{qC1}$, E Hydration & 9 & 2 & 0.931 & 0.227 & 19.506 & 0.0024 & 0.685 & 0.348 & 0.301 \\
\hline & Equation & \multicolumn{9}{|c|}{$\log I C_{50}=+4.0200( \pm 2.6086) \mathrm{qC} 1+0.1221( \pm 0.0491)$ E Hydra $+3.3811( \pm 0.3852)$} \\
\hline
\end{tabular}

$\mathrm{n}=$ number of data, $\mathrm{m}=$ number of variable, $\mathrm{R}=$ correlation coefficient, $\mathrm{s}=$ standard error, $\mathrm{F}=$ Fisher coefficient, SPress = Predictive Error Sum of Squares. 
The best equation model generated from QSAR study of S. aureus is $\log$ IC $_{50}=-7.5725( \pm 2.9753)$ qC11-6.0978 $( \pm 0.7519)$ qC15-7.9387 $( \pm 1.3551)$ qC16-8.3101 $( \pm 1.7492)$ qC17+0.0061 ( \pm 0.0010$)$ Volume$5.5336( \pm 1.3713)$. The equation was used to design new HGV, PGV and GVT analog with antibacterial activities against $S$. aureus. Based on the model, the five variables (qC11, qC15, qC16, qC17, Volume) have significant effects on $\mathrm{IC}_{50}$ value. The model has $\mathrm{R}$ correlation (0.988), Fisher coefficient (171.1336), s value (0.052) and PRESS statistic (0.194), showing that the model is closed to the experimental results.

Table 3: Statistical model QSAR and parameter statistical of MLR result against B. subtilis

\begin{tabular}{|c|c|c|c|c|c|c|c|c|c|c|}
\hline No. & Descriptor & $\mathbf{n}$ & $\mathbf{m}$ & $\mathbf{R}$ & $\mathbf{s}$ & $\mathbf{F}$ & $\mathbf{p}$ & Q2 & SPress & SDep \\
\hline \multirow[t]{2}{*}{1.} & $\begin{array}{l}\text { qC3, qC7, qC14, E Homo, E } \\
\text { Lumo }\end{array}$ & 10 & 5 & 0.999 & 0.022 & 314.092 & $<0.0001$ & 0.985 & 0.054 & 0.036 \\
\hline & Equation & \multicolumn{9}{|c|}{$\begin{array}{l}\log I C_{50}=-2.1710( \pm 0.2592) \mathrm{qC} 3-10.9207( \pm 3.0630) \mathrm{qC} 7+1.9909( \pm 0.3572) \mathrm{qC} 14+1.1712( \pm 0.2004) \text { E Homo- } \\
0.1840( \pm 0.1227) \mathrm{E} \text { Lumo }+13.1381( \pm 1.6947)\end{array}$} \\
\hline \multirow[t]{2}{*}{2.} & qC3, qC7, qC14, E Homo & 10 & 4 & 0.993 & 0.046 & 91.018 & 0.0001 & 0.946 & 0.093 & 0.069 \\
\hline & Equation & \multicolumn{9}{|c|}{$\begin{array}{l}\log I C_{50}=-2.2830( \pm 0.4747) \mathrm{qC} 3-7.3596( \pm 3.7010) \mathrm{qC} 7+2.3556( \pm 0.5006) \mathrm{qC} 14+0.9164( \pm 0.2034) \mathrm{E} \\
\text { Homo }+11.0401( \pm 1.8293)\end{array}$} \\
\hline \multirow[t]{2}{*}{3.} & qC14, EHomo, EHydration & 10 & 3 & 0.973 & 0.084 & 35.699 & 0.0003 & 0.872 & 0.130 & 0.106 \\
\hline & Equation & \multicolumn{9}{|c|}{$\log I C_{50}=+2.2158( \pm 0.8318) \mathrm{qC} 14+0.7866( \pm 0.3162) \mathrm{E}$ Homo $+0.0650( \pm 0.0194) \mathrm{E}$ hydr $+10.2998( \pm 2.9280)$} \\
\hline \multirow[t]{2}{*}{4.} & $\mathrm{qC} 2, \mathrm{qC} 3$ & 10 & 2 & 0.881 & 0.159 & 12.138 & 0.0053 & 0.625 & 0.206 & 0.182 \\
\hline & Equation & \multicolumn{9}{|c|}{$\log I C_{50}=+3.4866( \pm 1.8956) \mathrm{qC} 2-1.7717( \pm 1.3208) \mathrm{qC} 3+2.8625( \pm 0.2275)$} \\
\hline
\end{tabular}

$\mathrm{n}=$ number of data, $\mathrm{m}=$ number of variable, $\mathrm{R}=$ correlation coefficient, $\mathrm{s}=$ standard error, $\mathrm{F}=$ Fisher coefficient, SPress $=$ Predictive Error Sum of Squares

Table 4: Statistical model QSAR and parameter statistical of MLR result against $E$. coli

\begin{tabular}{|c|c|c|c|c|c|c|c|c|c|c|}
\hline No. & Descriptor & $\mathbf{n}$ & m & $\mathbf{R}$ & $\mathbf{s}$ & $\mathbf{F}$ & $\mathbf{p}$ & Q2 & SPress & SDep \\
\hline \multirow[t]{2}{*}{1.} & $\begin{array}{l}\mathrm{qC} 2, \mathrm{qC} 11, \mathrm{qC} 12, \mathrm{E} \\
\text { Hydration, Mass }\end{array}$ & 9 & 5 & 1.000 & 0.008 & 2954.907 & $<0.0001$ & 0.981 & 0.074 & 0.045 \\
\hline & Equation & $\begin{array}{l}\text { Lo } \\
\text { hy }\end{array}$ & 00 & $\begin{array}{l}305( \pm 0 \\
0.0003\end{array}$ & $\begin{array}{r}\mathrm{qC} 2+6 \\
+2.743\end{array}$ & $\begin{array}{l}( \pm 0.5069) q \\
0978)\end{array}$ & $726( \pm 0.5$ & $12+0.1$ & $0.0067) \mathrm{E}$ & \\
\hline \multirow[t]{2}{*}{2.} & $\begin{array}{l}\text { qC2, qC13, E Hydration, } \\
\text { Surface Area (SA) }\end{array}$ & 10 & 4 & 0.993 & 0.046 & 91.018 & 0.0001 & 0.946 & 0.093 & 0.069 \\
\hline & Equation & & 206 & $\begin{array}{l}354( \pm 0 \\
2315)\end{array}$ & $\mathrm{qC} 2-0$ & $\pm 0.2637) \mathrm{q}$ & $850( \pm 0.00$ & $y d r+0$ & $0.0004)$ & \\
\hline \multirow[t]{2}{*}{3.} & qC4, qC16, Surface Area (SA) & 9 & 3 & 0.994 & 0.047 & 132.012 & $<0.0001$ & 0.944 & 0.100 & 0.079 \\
\hline & Equation & Lo & $50=$ & $541( \pm 1$ & $\mathrm{qC} 4+2$ & $( \pm 0.5855)$ & $0016( \pm 0$. & $A+2.99$ & $.4357)$ & \\
\hline \multirow[t]{2}{*}{4.} & $\mathrm{qC} 4, \mathrm{qC} 16$ & 9 & 2 & 0.955 & 0.114 & 30.878 & 0.0007 & 0.708 & 0.208 & 0.180 \\
\hline & Equation & Lo & $50=$ & $988( \pm 2$ & $\mathrm{qC} 4+3$ & $( \pm 1.2774) \mathrm{q}$ & $190( \pm 0.4$ & & & \\
\hline
\end{tabular}

$\mathrm{n}=$ number of data, $\mathrm{m}=$ number of variable, $\mathrm{R}=$ correlation coefficient, $\mathrm{s}=$ standard error, $\mathrm{F}=$ Fisher coefficient, SPress $=$ Predictive Error Sum of Squares

Table 5: The comparison between calculated and experimental antibacterial activity $\left(\log I C_{50}\right)$ against $S . a$ ureus, $B$. subtilis and $E$. coli by BuildQSAR

\begin{tabular}{|c|c|c|c|c|}
\hline No. & Bacteria & Comp & Log $\mathrm{IC}_{50}$ experimental & Log IC $_{50}$ calculation \\
\hline \multirow[t]{9}{*}{1.} & S. aureus & A103 & 1.43 & 1.47 \\
\hline & & A114 & 1.91 & 1.88 \\
\hline & & A101 & 3.02 & 3.08 \\
\hline & & B101 & 2.66 & 2.64 \\
\hline & & C101 & 2.66 & 2.68 \\
\hline & & B115 & 2.83 & 2.82 \\
\hline & & B145 & 2.78 & 2.80 \\
\hline & & A150 & 3.05 & 3.05 \\
\hline & & C150 & 2.39 & 2.44 \\
\hline \multirow[t]{10}{*}{2.} & B. subtilis & A143 & 2.41 & 2.41 \\
\hline & & C143 & 2.26 & 2.27 \\
\hline & & A113 & 2.07 & 2.09 \\
\hline & & B113 & 1.92 & 1.90 \\
\hline & & A101 & 2.71 & 2.72 \\
\hline & & B101 & 2.65 & 2.65 \\
\hline & & C101 & 2.70 & 2.70 \\
\hline & & B115 & 2.74 & 2.72 \\
\hline & & B145 & 2.66 & 2.67 \\
\hline & & $\mathrm{C} 150$ & 2.65 & 2.65 \\
\hline \multirow[t]{9}{*}{3.} & E. coli & A143 & 2.37 & 2.38 \\
\hline & & C143 & 2.23 & 2.25 \\
\hline & & B113 & 1.71 & 1.74 \\
\hline & & A103 & 2.22 & 2.24 \\
\hline & & A145 & 2.55 & 2.57 \\
\hline & & A150 & 2.60 & 2.62 \\
\hline & & C101 & 2.79 & 2.80 \\
\hline & & B145 & 2.60 & 2.62 \\
\hline & & B150 & 2.71 & 2.74 \\
\hline
\end{tabular}


The best equation model generated from QSAR study of B. subtilis is Log $\mathrm{IC}_{50}=-2.1710( \pm 0.2592) \mathrm{qC} 3-10.9207( \pm 3.0630) \mathrm{qC} 7+1.9909( \pm 0.3572)$ $\mathrm{qC} 14+1.1712( \pm 0.2004)$ E Homo-0.1840 $( \pm 0.1227)$ E Lumo+13.1381 $( \pm 1.6947)$. The equation was used to design new HGV, PGV and GVT analog with antibacterial activities against B. subtilis. Based on the model, the five variables (qC3, qC7, qC14, EHomo, ELumo) have significant effects on $\mathrm{IC}_{50}$ value. The model has $\mathrm{R}$ correlation (0.999), Fisher coefficient (314.092), s value (0.022) and PRESS statistic (0.054), showing that the model is closed to the experimental results.

The best equation model generated from QSAR study of $E$. coli is Log $\mathrm{IC}_{50}=+7.5805 \quad( \pm 0.4244) \quad \mathrm{qC} 2+6.7449 \quad( \pm 0.5069) \quad \mathrm{qC} 11+1.6726$ $\begin{array}{llllll}( \pm 0.5181) & \mathrm{qC} 12+0.1204 & ( \pm 0.0067) & \mathrm{E} & \mathrm{hydr}+0.0031 & ( \pm 0.0003)\end{array}$
Mass $+2.7435( \pm 0.0978)$. The equation was used to design new HGV, PGV and GVT analog with antibacterial activities against E. coli. Based on the model, the five variables (qC2, qC11, qC12, E Hydration, Mass) have significant effects on $\mathrm{IC}_{50}$ value. The model has $\mathrm{R}$ correlation $(1,000)$, Fisher coefficient (2954.907), s value (0.008) and PRESS statistic (0.074), showing that the model is closed to the experimental results.

The prediction of antibacterial activities against $S$. aureus, B. subtilis, and E. coli of 9 to 10 test set which was resulted from the best equation was compared and plotted with experimental data using linear regression calculation to identify the correlation of each equation as shown in table 5 and fig. 2 .

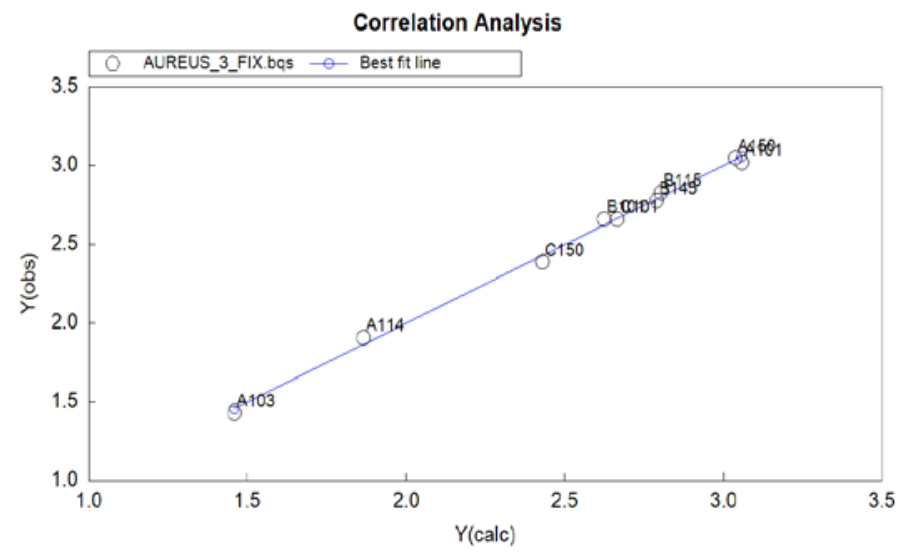

(a)

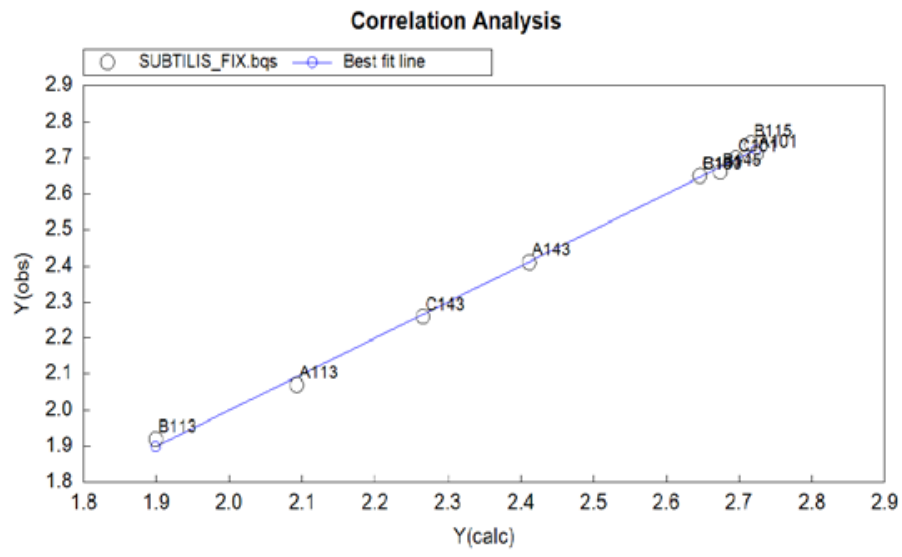

(b)

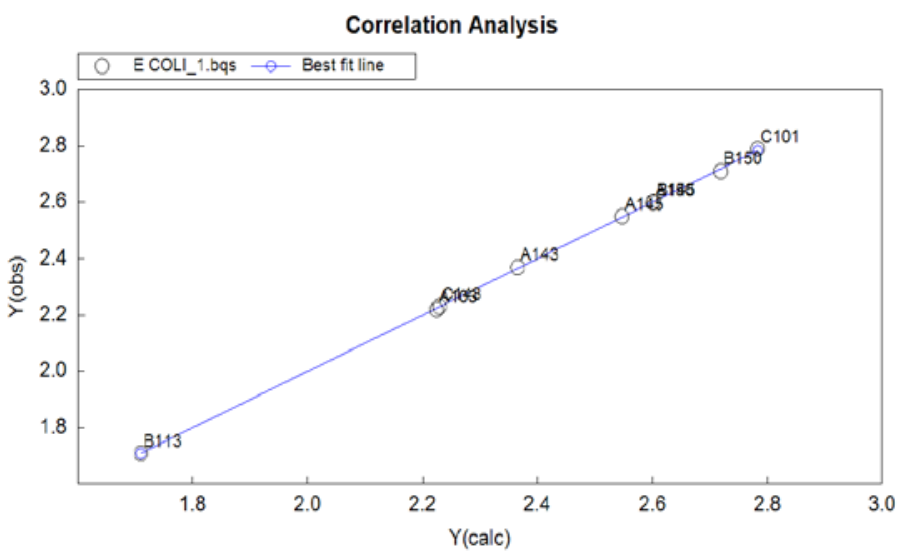

(C)

Fig. 2: The correlation analysis of result MLR statistical between calculation $\left(\log I C_{50}\right)$ and experimental $\left(\log I C_{50}\right)($ a) $S$. aureus, (b) $B$. subtilis, (c) E. Coli 
The best QSAR equation model was used as the guideline of predicting the antibacterial activities against $S$. aureus, B. subtilis and E. coli in designing the ratio of HGV, PGV, and GVT analog. The substituents of R1 to R5 were substituted into a new molecule as the descriptor that will influence the antibacterial activities.

Based on the equation 1 in table 2, to generate the best antibacterial activities against $S$. aureus the charge of atom C11, C15, C16 and C17 must be positive for small $\log \mathrm{IC}_{50}$. The positive charge of atom $\mathrm{C} 15$, C16 and C17 can be generated by adding electronegative substituents such as hydroxyl and halogen. To influence the positive charge of atom C11, either hydroxyl or halogen was added to the nearest or neighbouring atom $\mathrm{C}$.

Based on the equation 1 in table 3 , to generate the best antibacterial activities against $B$. subtilis the charge of atom C3, C7, and C14 must be positive for small $\mathrm{Log} \mathrm{IC}_{50}$. The positive charge of atom $\mathrm{C} 3$ and C14 can be generated by adding electronegative substituents such as hydroxyl and halogen. To influence the positive charge of atom C7, either hydroxyl or halogen was added to the nearest or neighboring atom C.

Based on the equation 1 in table 4 , to generate the best antibacterial activities against $E$. coli. The charge of atom C2, C11 and C12 must be negative for small $\log \mathrm{IC}_{50}$. The negative charge of atom $\mathrm{C} 2$ can be generated by adding electronegative substituents such as- $\mathrm{OH}$ andOR. To influence the negative charge of atom $\mathrm{C} 11$ and $\mathrm{C} 12$, either hydroxyl or halogen was added to atom C13 and C17 due to its resonance effect that can make the charge of atom C9 and C14 more negative. The numbering structure of atom $\mathrm{C}$ in the basic structure is shown in fig. 3.

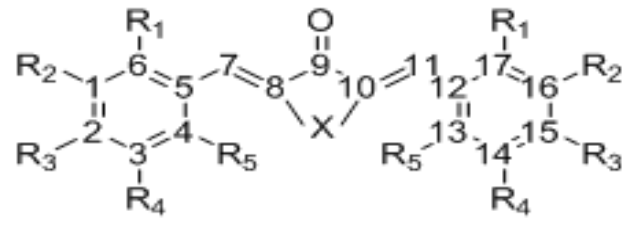

$$
\text { Seri } A=X=\left(\mathrm{CH}_{2}\right)_{3}
$$$$
\text { Seri } B=X=\left(\mathrm{CH}_{2}\right)_{2}
$$

Fig. 3: The numbering structure of the $C$ atom in HGV, PGV, GVT analogues basic structure

New analogue of HGV, PGV, and GVT with better antibacterial activities against $S$. aureus, B. subtilis, and E. coli is revealed from the value of IC 50 as shown in table 6 , table 7 , and table 8 . A113 was selected for synthesis as its compound design has the potential of antibacterial activities against $S$. aureus, B. subtilis and E. coli.

Table 6: Design new HGV, PGV and GVT analogues and its predicted antibacterial activity against $S$. aureus calculated using the best QSAR model

\begin{tabular}{llllllll}
\hline No. & Comp & \multicolumn{2}{c}{ Substitute } & & & & Log $\boldsymbol{I C}_{50}$ predict \\
\cline { 2 - 6 } & & R1 & R2 & R3 & R4 & R5 & \\
\hline 1 & $\mathrm{~A} 113$ & $\mathrm{H}$ & $\mathrm{Br}$ & $\mathrm{OH}$ & $\mathrm{Br}$ & $\mathrm{H}$ & 1.84 \\
2 & $\mathrm{C} 113$ & $\mathrm{H}$ & $\mathrm{Br}$ & $\mathrm{OH}$ & $\mathrm{Br}$ & $\mathrm{H}$ & 1.72 \\
\hline
\end{tabular}

Table 7: Design new HGV, PGV and GVT analogues and its predicted antibacterial activity against $B$. subtilis calculated using the best QSAR model

\begin{tabular}{llllllll}
\hline No. & Comp & \multicolumn{2}{l}{ Substitute } & & & & \multirow{2}{*}{$\log \boldsymbol{I C}_{50}$ predict } \\
\cline { 3 - 7 } & & R1 & R2 & R3 & R4 & R5 & \\
\hline 5 & $\mathrm{~A} 113$ & $\mathrm{H}$ & $\mathrm{Br}$ & $\mathrm{OH}$ & $\mathrm{Br}$ & $\mathrm{H}$ & 1.79 \\
\hline
\end{tabular}

Table 8: Design new HGV, PGV and GVT analogues and its predicted antibacterial activity against $E$. coli calculated using the best QSAR model

\begin{tabular}{llllllll}
\hline No. & Comp & Substitute & & & \multicolumn{2}{c}{ Log IC predict } \\
\cline { 3 - 6 } & & R1 & R2 & R3 & R4 & R5 & H \\
\hline 1 & $\mathrm{~A} 113$ & $\mathrm{H}$ & $\mathrm{Br}$ & $\mathrm{OH}$ & $\mathrm{Br}$ & $\mathrm{H}$ & 1.89 \\
2 & $\mathrm{C} 113$ & $\mathrm{H}$ & $\mathrm{Br}$ & $\mathrm{OH}$ & $\mathrm{Br}$ & $\mathrm{H}$ & 1.54 \\
\hline
\end{tabular}

Docking studies of 2,6-bis((E)-3,5-dibromo-4-hydroxybenzylidene) cyclohexan-1-one (A113)

In this research, in silico evaluation was performed for A113 as an antibacterial. A113 was docked into the $\beta$-lactam receptor, according to the formation stages of peptidoglycan, the basic component of DAlanil-D-Alanine formation. The transport enzyme of D-Alanil-DAlanin is D-Alanil-D-Alanine decarboxylase (DACA). The enzyme is provided by protein data bank with PDB ID code: 3MZE. Protein contains a reference molecule that is cefoxitin as native ligand [13].

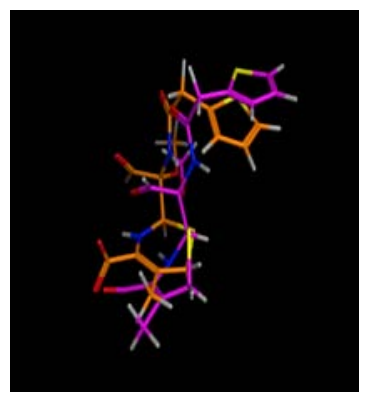

Fig. 4: Alignment of native ligand (purple) and docked ligand (yellow)
The validation of molecular docking protocol was performed to ensure that the receptors are proper to use in the molecular docking process. Based on the validation process, the obtained root mean square deviation (RMSD) is $1.7753 \AA$. It is less than $2 \AA$ indicating that the docking protocol with receptor PDB 3MZE is valid and feasible for the advanced docking process (fig. 4) [15].

Based on the docking results, conformations and the best favorable docking poses with the maximum number of interactions were analyzed; they were considered as negative s by MOE software. Furthermore, the best docking pose of 10 conformations of each compound was analyzed for further investigation of any interactions resulted in using active residual sites. The lowest binding energy (s) with the most interaction number is compounded with high potential of antibacterial agents [17]. The docking results reveal proper binding poses with a strong interaction of active residual sites of the protein. The 2D-protein ligand interaction was visualized using MOE and shown in table 9.

The docking result of A113 and amoxicillin using receptor PDB ID 3MZE showed docking score (s) of 13.2599. It is much lower than the docking score of cefoxitin, a native ligand, $(-10.8382)$ and amoxicillin (-11.5230). The docking score of amoxicillin is higher than of A113 and lower than of cefoxitin as the antive ligand. This means that A113 is more active as antibacterial than amoxicillin. Therefore, A113 was considered as the potential antibacterial 
compound. The lower docking score with proper pose results in better stability levels of ligand and receptor [16]. The lower binding energy (s), the bigger possibility to accept the experimental compounds as medicine [17-20].

Table 9: Docking results with protein PDB ID 3MZE

\begin{tabular}{|c|c|c|c|c|c|c|c|}
\hline Compound & $\mathbf{S}$ & Rmsd_refine & E_conf & E_place & E_score 1 & E_refine & No. of Conf \\
\hline A113 & -13.2599 & 3.31144 & 23.9537 & -42.0713 & -10.8615 & -35.9689 & 10 \\
\hline Amoxicillin & -11.5230 & 0.8853 & 53.8637 & -67.6785 & -11.1618 & -32.3243 & 10 \\
\hline Cefoxitin & -10.8382 & 2.6991 & 65.8911 & -74.7419 & -11.2002 & -40.5919 & 10 \\
\hline
\end{tabular}

S-The final score, rmsd_refine-The root mean square deviation between the pose before refinement and the pose after refinement, E_conf-The energy of the conformer. E_place-Score from the placement stage, E_score1-Score from the rescoring stage(s), E_refine-Score from the refinement stage and No. of conf-number of conformations generated by ligand.

The best docking pose and ligand interaction were selected from each compound of A113, amoxicillin, and cefoxitin; they formed a cluster in active site gap of the receptors as shown in fig. 5, fig. 6, and fig. 7 .
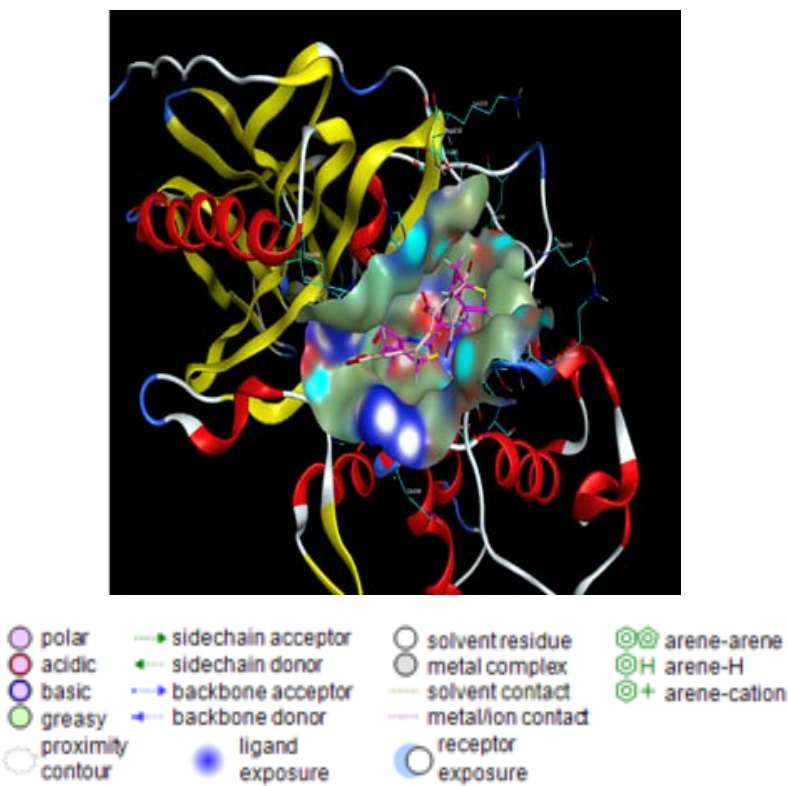

Fig. 5: Binding surface and ligand interaction of compound A113 with 3MZE
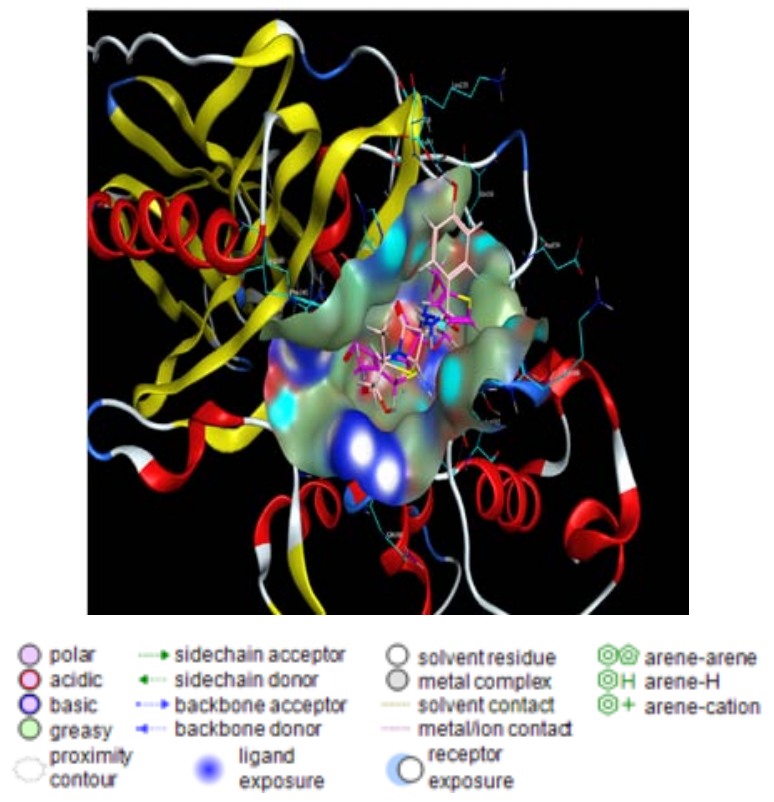

Fig. 6: Binding surface and ligand interaction of compound amoxicillin with $3 \mathrm{MZE}$

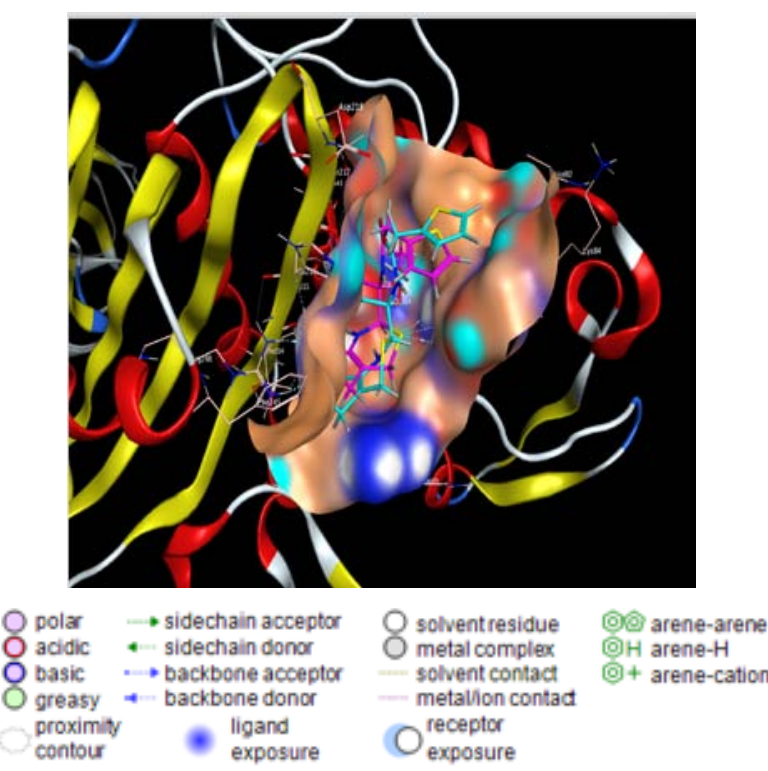

Fig. 7: Binding surface and ligand interaction of compound cefoxitin with $3 \mathrm{MZE}$

The docking results reveal that 0 substituent $(\mathrm{C}=\mathrm{O}, \mathrm{O}-\mathrm{H})$ of $\mathrm{A} 113$ compound has interaction with Asn A112, Asn B112 (same as amoxicillin) and Asp A11, Asp B11 residue through sidechain acceptor and sidechain donor. Besides that, the aromatic ring of compound A113 has an interaction with Leu A153, B153 residue through the arene- $\mathrm{H}$ bond. In amoxicillin, atom $\mathrm{O}$ of the $\beta$-lactam ring has interaction on Asn A112 and B112 residue through sidechain acceptor; whereas, the S group of an aromatic ring has interaction with Ser B44, Ser A110, and B110 residue through sidechain acceptor. In cefoxitin, atom $\mathrm{O}(\mathrm{C}=0)$ has interaction with His A216, B126 and Ser A44, B44 residue through backbone acceptor. Atom $S$ has an interaction with Ser A86, B86, A87, B87 residue through backbone acceptor (fig. 5, 6, and 7). The confirmation energy of A113 compound, amoxicillin and cefoxitin is $23.9537,53.8637$, and 65.8911 respectively, indicating the active compounds of the confirmation energy.

In vitro evaluation of 2,6-bis((E)-3,5-dibromo-4-hydroxybenzylidene) cyclohexan-1-one (A113)

The in vitro evaluation of antibacterial activities was performed using dilution method on some bacteria species represented by Gram-positive and Gram-negative bacteria. Table 10 and fig. 8 show good inhibitory activities 2,6-bis((E)-3,5-dibromo-4-hydroxybenzylidene) cyclohexan-1-one (A113) against S. aureus, B. subtilis and $E$. coli. The Inhibitory Concentration 50 (IC ${ }_{50}$ ) A113 againts $S$. aureus, B. subtilis, and E. coli is $27.3 \mu \mathrm{g} / \mathrm{ml}, 30.9 \mu \mathrm{g} / \mathrm{ml}, 32 \mu \mathrm{g} / \mathrm{ml}$ respectively. A113 is a potential compound for advanced study.

Atom $\mathrm{Br}$ and $\mathrm{OH}$ of $\mathrm{A} 113$ is essential for its antibacterial activities. It is shown by the conducted docking study. However, some previous studies reveal that $\mathrm{OH}$ group has also essential roles to inhibit the bacterial activities. 
Table 10: IC 50 value of A113 against S. aureus, B. subtilis and E. coli

\begin{tabular}{ll}
\hline Bacteria & IC $_{\mathbf{5 0}}(\boldsymbol{\mu g} / \mathbf{m l})$ \\
\hline S. aureus & 27.3 \\
B. subtilis & 30.9 \\
E. coli & 32 \\
\hline
\end{tabular}
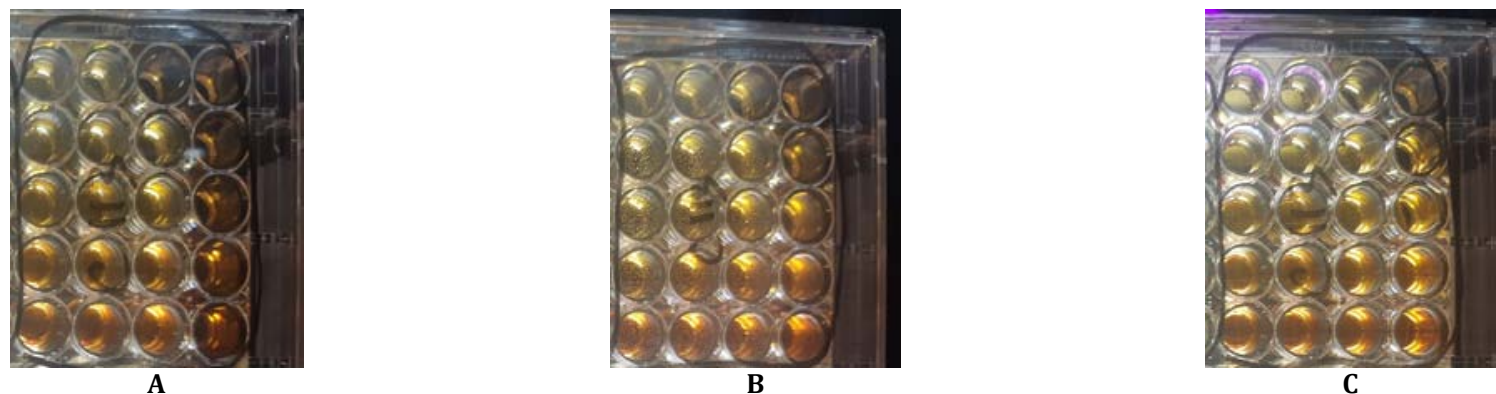

Fig. 8: The result dilution test of A113 against S. aureus (A), E. coli (B), B. subtilis (C)

\section{CONCLUSION}

The results of the research reveal that compound 2,6-bis((E)-3,5dibromo-4-hydroxybenzylidene)cyclohexan-1-one (A113), the result of QSAR study using BuildQSAR, is a new design of GVT analog proven to have antibacterial activities against $S$. aureus, B. subtilis dan E. coli. A113 is potential to be used as drug with antibacterial activities through interaction and PBP5 inhibition confirmed by docking studies.

\section{ACKNOWLEDGEMENT}

The authors are grateful to Medicinal Chemistry Department, Faculty of Pharmacy, and Department of chemistry, faculty of Mathematics and Natural Sciences, Universitas Gadjah Mada, Yogyakarta, Indonesia for carrying out the research.

\section{AUTHORS CONTRIBUTIONS}

All the author have contributed equally

\section{CONFLICT OF INTERESTS}

The authors confirm that this article content has no conflicts of interest.

\section{REFERENCES}

1. Sardjiman, Reksohadiprojo MS, Hakim L, Van der Goot $\mathrm{H}$, Timmerman H. 1,5-Diphenyl-1,4-pentadiene-3-ones and cyclic analogues as antioxidative agents. Synthesis and structureactivity relationship. Eur J Med Chem 1997;32:625-30.

2. Purwanggana A, Mumpuni E, Mulatsari E. In vitro and in silico antibacterial activity of 1.5-bis (3'-ethoxy-4'-hydroxyphenyl)-14-pentadiene-3-one. Int J Pharm Pharm Sci 2018;10:70-6.

3. Sardjiman, Yuliarti NN, Sasmito, Nugroho EA. Synthesis and evaluation of antioxidant and anti-inflammatory activities of 2-(4'-dimethylamino-benzylidenen)-6-benzylidene cyclohexanone. Indonesian J Pharm 2013;24:198-205.

4. McGhie EJ, Brawn LC, Hume PJ, Humphreys D, Koronakis V. Salmonella takes control: effector-driven manipulation of the host. Curr Opin Microbiol 2009;12:117-24.

5. Hai-long Z, Shimin C, Yalan L. Some Chinese folk prescriptions for wind-cold type common cold. J Tradit Complement Med 2015;5:135-7.

6. Ortayli N, Ringheim K, Collins L, Sladden T. Sexually transmitted infections: progress and challenges since the 1994 international conference on population and development (ICPD). Contraception 2014;90 Suppl 6:S22-S31.

7. Lenin HH, Lauro FV, Elodia GV, Maria LR, Socorro HM, Regina CC. Antibacterial activity exerted by some Diazabicyclo-steroid derivatives against Staphylococcus aureus and Streptococcus pneumoniae. Orient J Chem 2017;33:2647-67.
8. Michna RH, Zhu B, Mader U, Stulke J. Subti wiki 2.0--an integrated database for the model organism Bacillus subtilis. Nucleic Acid Res 2016;44:D654-D662.

9. Prawono HD, Tahir I, Widiatmoko A. Quantitative relationship of electronic structure and inhibition activity of curcumin analogs on ethoxyresorufin 0-dealkylation (EROD) reaction. Indonesia J Chem 2010;7:78-82.

10. Istyastono EP, Martono S, Prawono HD, Tahir I. Quantitative structure-activity relationship analysis of curcumin and its derivatives as GST inhibitors based on computational chemistry calculation. Indonesia J Chem 2013;3:179-86.

11. Dharajiya D, Jasani H, Khatrani T, Kapuria M, Pachchigar K, Patel P. Evaluation of antibacterial and antifungal activity of fenugreek (Trigonella foenum-graecum) extracts. Int J Pharm Pharm Sci 2016;8:212-7.

12. Dharajiya D, Patel P, Patel M, Moitra N. In vitro antimicrobial activity and qualitative phytochemical analysis of Withania somnifera (L.) dunal extracts. Int J Pharm Sci Rev Res 2014;27:349-54.

13. Nicola G, Joshua T, Pratt RF, Nicholas RA, Davies C. Crystal structures of covalent complexes of $\beta$-lactam antibiotics with Escherichia coli penicillin-binding protein 5: toward an understanding of antibiotic specificity. Biochemistry 2010;49:8094-104.

14. Kubinyi H. Quantitative structure-activity relationships. 2. A mixed approach, based on hansch and free-wilson analysis. J Med Chem 1976;5:587-600.

15. Yuniarti N, Nugroho PA, Asyhar A, Sardjiman, Ikawati Z, Istyastono EP. In vitro and in silico studies on curcumin and its analogues as dual inhibitors for cyclooxygenase-1 (COX-1) and cyclooxygenase-2 (COX-2). ITB J Sci 2012;44A:51-66.

16. Syahri J, Yuanita E, Nurohmah BA, Wathon $\mathrm{MH}$, Syafri R, Armunanto R, et al. Chalcone analogue as potent anti-malarial compounds against Plasmodium falciparum: synthesis, biological evaluation, and docking simulation study. Orient J Chem 2017;33:29-40.

17. Korb O, Stutzle T, Exner TE. Empirical scoring functions for advanced protein-ligand docking with PLANTS. J Chem Inf Model 2009;49:84-96.

18. Kumar KM, Anitha P, Sivasakthi V, Bag S, Lavanya P, Anbarasu $\mathrm{A}$, et al. In silico study on penicillin derivatives and cephalosporins for upper respiratory tract bacterial pathogens. 3 Biotech 2014;4:241-51.

19. Balavignesh V, Srinivasan E, Ramesh Babu NG, Saravanan N. Molecular docking study on NS5B polymerase of hepatitis $\mathrm{c}$ virus by a screening of volatile compounds from acacia concinna and ADMET prediction. Int J Pharm Life Sci 2013;4:2548-58.

20. Thangavelu P, Chellapa S, Thangavel S. Synthesis, evaluation and docking studies of novel formazan derivatives as an enoylACP reductase inhibitor. Int J Pharm 2018;8:56-61. 